\title{
Impact on Mechanical Properties of Hybrid Aluminum Metal Matrix Composites
}

\author{
P. Sri Ram Murthy, Y. Seetha Rama Rao
}

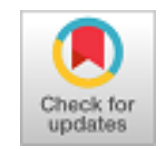

\begin{abstract}
Hybrid composites are those composites which have a combination of two or more reinforcements in a single matrix. In this study, Hybrid Aluminum Metal Matrix Composites were fabricated by using Stir Casting technique. Hybrid composites with three reinforcements such as Aluminum oxide $\left(\mathrm{Al}_{2} \mathrm{O}_{3}\right)$, Silicon Carbide (SiC) and Boron Carbide $\left(\mathrm{B}_{4} \mathrm{C}\right)$ in different proportions are considered and Aluminum alloy 6061-T6 (AI6061) as base alloy matrix. Later, the cast aluminum metal matrix composites were machined as per ASTM standards with required dimensions. Mechanical tests such as tensile, flexural, Charpy impact, Brinell Hardness tests were conducted on the composites fabricated inorder to evaluate effect of reinforcements. Morphological study of the composites is carried out by using Scanning electron microscope (SEM). The test results were studied and analyzed.
\end{abstract}

Index Terms: Al6061-T6 alloy, Alumina, Boron Carbide, Stir Casting, Silicon Carbide, Mechanical Properties, SEM.

\section{INTRODUCTION}

Metal Matrix Composites (MMC) are made by dispersing the reinforcements in metal matrix. These reinforcements can be of metals, ceramics and organic compounds. Reinforcements are added to improve the properties of base metal in all disciplines such as physical, mechanical and electrical [1]. Mechanical properties such as stiffness, strength, flexural rigidity, hardness etc. increases in composites when compared to base metal [2, 3]. Many designers have many conceptions to their desired components and metal matrix composites fulfill all the requirements and produces new castings with specific demands along with new engineering applications. Generally, metals such as titanium, steel, magnesium, nickel, copper and aluminum are preferred to produce MMC $[4,5]$. Out of these, aluminum is widely used for its light weight, high stiffness, strength, good mechanical and electrical properties, good reflective properties, impermeability and cost effectiveness [6, 7]. More additional attributes such as good corrosion resistance and better damping capacitance can be extracted through Aluminum Metal Matrix Composites (AMMC). AMMC are widely used in automobile, aircraft, marine, aerospace and in various fields $[8,9]$. The performance of these materials mainly depends on selecting the right combination of reinforcing materials.

\section{Revised Manuscript Received on October 30, 2019.}

* Correspondence Author

P. Sri Ram Murthy*, PG Student-M. Tech (CAAD), Department of Mechanical Engineering, Gayatri Vidya Parishad College of Engineering (Autonomous), Visakhapatnam, India, Phn: 8297161726, Email: srm.paladugu02@gmail.com

Y. Seetha Rama Rao, Associate Professor, Department of Mechanical Engineering, Gayatri Vidya Parishad College of Engineering (Autonomous), Visakhapatnam, India, Phn: 9866070401, Email: yseetharamarao24@gvpce.ac.in

(c) The Authors. Published by Blue Eyes Intelligence Engineering and Sciences Publication (BEIESP). This is an open access article under the CC BY-NC-ND license (http://creativecommons.org/licenses/by-nc-nd/4.0/)
Generally, ceramics such as silicon carbide, fly ash, graphene, alumina etc. are used as major reinforcements [10, 11]. Aluminium Alloy 6061 is choosed as the base metal alloy matrix, Because it has moderate to high strength, high corrosion resistance and good weldability. Stir Casting method is generally preferred for aluminium composite fabrication as it has high flexibility and overall cost is effective [12, 13].

\section{MATERIALS AND METHODS}

\section{A. Matrix:}

Al 6061-T6 alloy is used as matrix, because of its ease availability. This alloy is precipitation hardened alloy containing magnesium and silicon has main elements. It has good mechanical properties such as good joining characteristics, good workability, moderate to high strength and good acceptance of applied coatings and it can be widely used in aircraft fittings, couplings, marine fittings, hydraulic pistons etc.

B. $\mathrm{Al}_{2} \mathrm{O}_{3}$ :

Aluminum oxide or Alumina is chemical composition of Aluminum and oxygen. It can be used as abrasives because of its high hardness. It has high thermal conductivity and good electrical insulation property. It can be used as cutting tool, body armor because of its high penetration and toughness capacitance.

C. $B_{4} C$ :

Boron Carbide is one of the best ceramic used in industries because of its excellent mechanical properties such as high strength, toughness, stiffness, hardness and low density. It is the third hardest material after diamond and boron nitride. It has good radiation ionizing stability and good neutron absorption capability. Boron Carbide can't be sintered without using sintering acids.

D. SiC:

Silicon Carbide has the excellent resistance to acids, alkalis, molten salts. It has high ductility property. It has high thermal conductivity and low thermal expansion which makes it to use as thermal shock resistant material.

\section{EXPERIMENT DETAILS}

\section{E. Stir Casting:}

Stir Casting also known as Rheo Casting. It is a liquid state fabrication technique used to produce castings. In this technique the base metal is melted to semi solid state and reinforcements are added into molten metal and stirred by using mechanical stirrer. Stirrer main function is to maintain uniform heat in the molten metal. After reaching the required viscosity of molten metal, the final composite can be solidified in die or mold. 


\section{Impact on Mechanical Properties of Hybrid Aluminum Metal Matrix Composites}

Stir Casting is cost effective and simplest technique and it is mostly used for fabrication of aluminum castings. Homogeneity of dispersed phase in the molten metal depends on the vortex created by the stirrer.

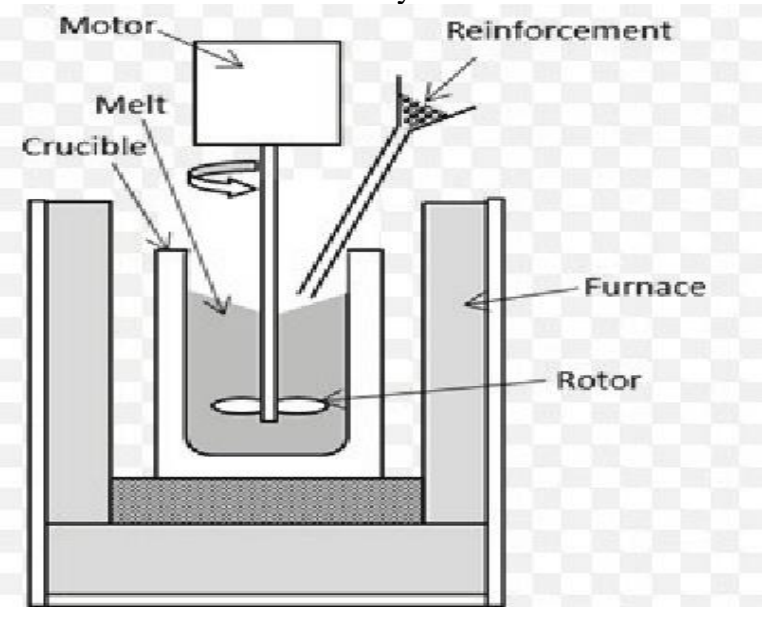

Figure 1: Stir Casting Equipment [14].

\section{SAMPLES DESCRIPTION}

Table 1: Chemical Composition of Al 6061-T6 alloy

\begin{tabular}{|c|c|c|c|c|c|}
\hline Si & $\mathbf{F e}$ & $\mathbf{C u}$ & Mn & Mg & $\mathrm{Cr}$ \\
\hline $\begin{array}{c}0.4- \\
0.8\end{array}$ & 0.7 & $\begin{array}{c}0.15- \\
0.4\end{array}$ & 0.15 & $0.8-0.120$ & $\begin{array}{c}0.04- \\
0.35\end{array}$ \\
\hline Zn & $\mathbf{T i}$ & $\begin{array}{c}\text { Others } \\
\text { each }\end{array}$ & $\begin{array}{c}\begin{array}{c}\text { Others } \\
\text { total }\end{array} \\
\text { tothe }\end{array}$ & Al6061 & \\
\hline 0.25 & 0.15 & 0.05 & 0.15 & Remainder & \\
\hline
\end{tabular}

Table 2: Composition of matrix and reinforcements in \% weight

\begin{tabular}{|c|c|c|c|c|}
\hline Samples & $\begin{array}{c}\mathbf{A l -} \\
\mathbf{6 0 6 1} \\
(\%)\end{array}$ & $\mathbf{A l}_{2} \mathbf{O}_{3}(\%)$ & $\mathbf{B}_{\mathbf{4}} \mathbf{C}(\%)$ & $\mathrm{SiC}(\%)$ \\
\hline 1 & 94 & 2 & 2 & 2 \\
\hline 2 & 94 & 3 & - & 3 \\
\hline 3 & 94 & - & 6 & - \\
\hline 4 & 100 & - & - & - \\
\hline
\end{tabular}

\section{FABRICATION OF ALUMINUM HYBRID COMPOSITES}

The detailed step by step process of fabrication was explained below.

Step 1: Initially the furnace was preheated and maintained at $900^{\circ} \mathrm{C}$. Later, the chopped Al-6061 alloy pieces were kept in crucible and placed in furnace.

Step 2: Then in the furnace the metal alloy is melted to semi solid state at $750^{\circ} \mathrm{C}$ and time taken for melting is 1.5 hour. Simultaneously reinforcement powders are wrapped in aluminium foil and were preheated at $400^{\circ} \mathrm{C}$ for removal of moisture.

Step 3: A degasser tablet named solid hexachloroethane $\left(\mathrm{C}_{2} \mathrm{Cl}_{6}\right)$ is used to remove moisture in molten metal. Now, the reinforcements were added in the semi solid molten metal in a three stage mixing process for properly distribution of dispersed phase.

Step 4: The solution is stirred in crucible by mechanical stirrer at 500rpm for five minutes. Now the stirred solution is taken out of the furnace and poured immediately into permanent mold casting which has four channels, so we can get four samples for each composition.

Step 5: Later, after solidifying the samples were taken out of the mold and the same process is repeated for the next two compositions.

Step 6: Total 12 samples were undergone secondary machining operations such as buffing, cutting, grinding, turning to attain the desired shapes as per ASTM standards. Tests such as Tensile, Hardness, Impact and flexural were conducted on the samples and results are compared with raw Al-6061 alloy.

\section{METHODOLOGY OF FABRICATION}

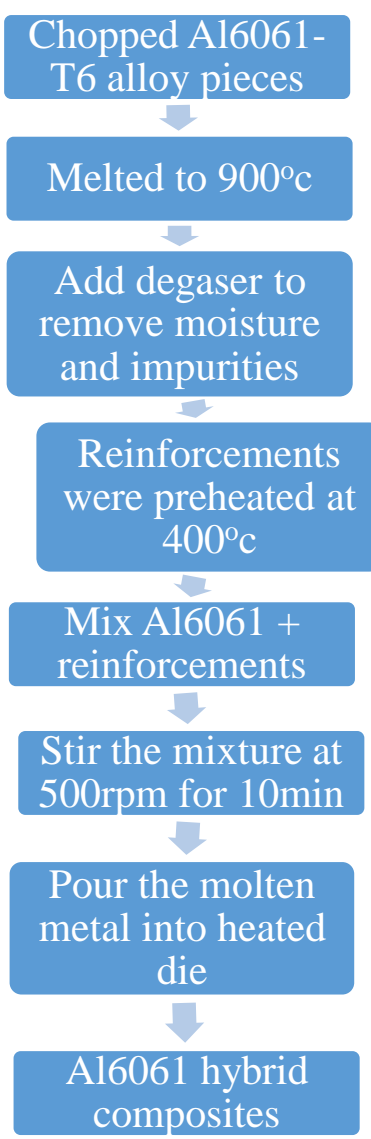

\section{TESTING}

F. Tensile Test:

Tensile test is also known as tension testing and is a fundamental material science and engineering test in which a sample is subjected to a controlled tension until failure. Specimens were prepared as per ASTM E8 standards and the test in done in Instron 8801 computerized universal testing machine, which can bear a max load of $100 \mathrm{KN}$. During the test, when sample is placed in the jaws and load is applied gradually, at certain point yielding starts and on further increase of load gives necking feature in samples and at certain point the machine detects the internal fracture in the sample and the point where the internal fracture occurs

Published By: 
is known as fracture point. The prepared samples are in the form, given below.

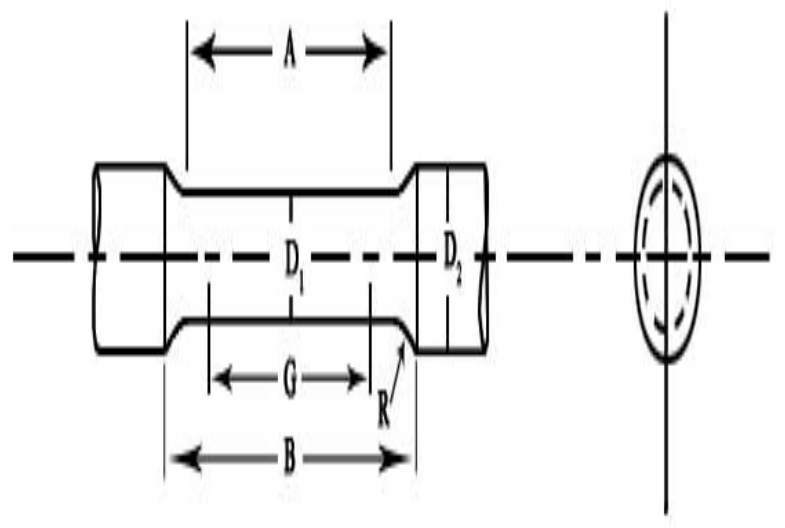

Figure2: Dimensions of Specimen as per ASTM standard

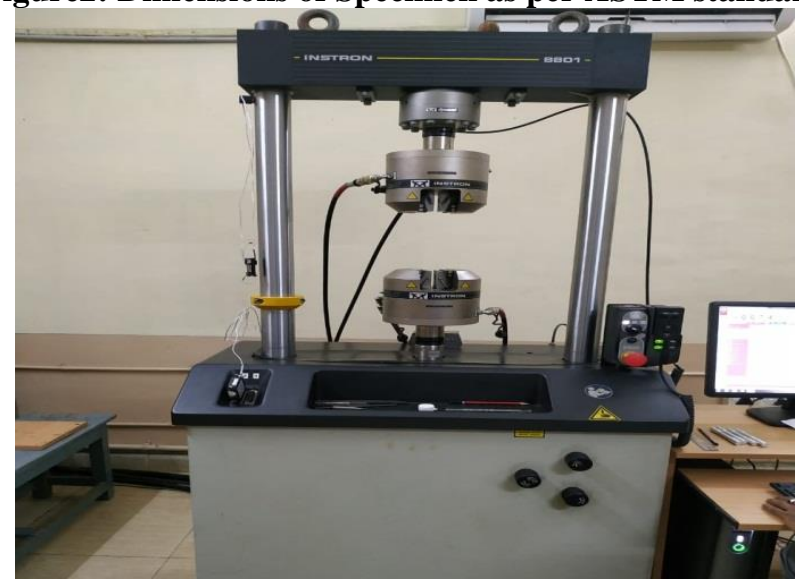

Figure 3: Instron 8801 Computerized UTM

$\mathrm{D}_{1}=$ Diameter of the narrow section $(10 \mathrm{~mm})$

$\mathrm{D}_{2}=$ Diameter of overall section $(12 \mathrm{~mm})$

$\mathrm{R}=$ Radius of curvature $(6 \mathrm{~mm})$

$A=$ Length of narrow section (50mm)

$\mathrm{G}=$ Gauge length $(40 \mathrm{~mm})$

$\mathrm{B}=$ Distance between grippers $(60 \mathrm{~mm})$

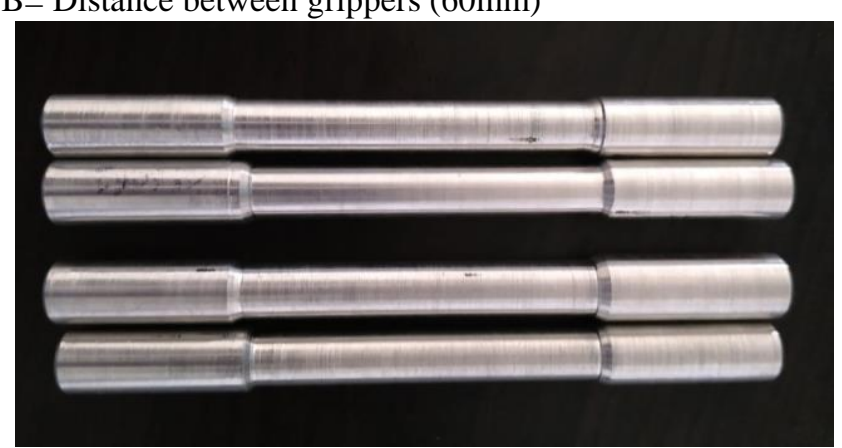

Figure 4: Composite samples before test

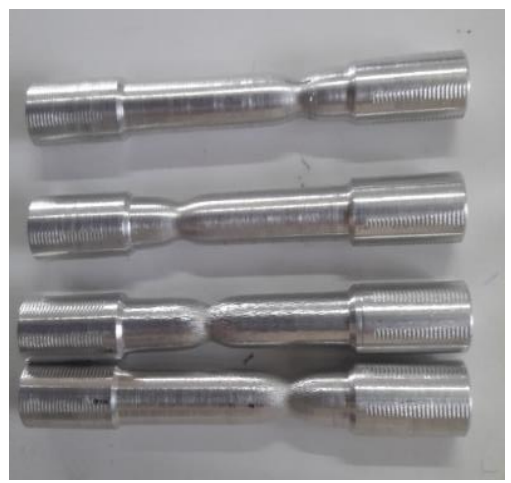

Figure 5: Composite samples after test

\section{G. Charpy Impact Test:}

Impact strength is the ability of material to withstand a suddenly applied load and it is expressed in terms of energy (Joules). An impact test signifies toughness of material which is the ability of material to absorb energy during plastic deformation. Specimens were prepared as per ASTM 370 standards. The samples are in the sizes of $10 \mathrm{~mm} \times$ $10 \mathrm{~mm} \times 55 \mathrm{~mm}$, and notch of depth $2 \mathrm{~mm}$ at center.

\section{Procedure:}

Placing the sample in vice jaw and fixing the hammer in pendulum at $120^{\circ}$ with respect to vertical post and initial energy posed by hammer is 300 Joules. Release the pendulum by operating the lever and note the pointer reading on scale after impact as final reading.

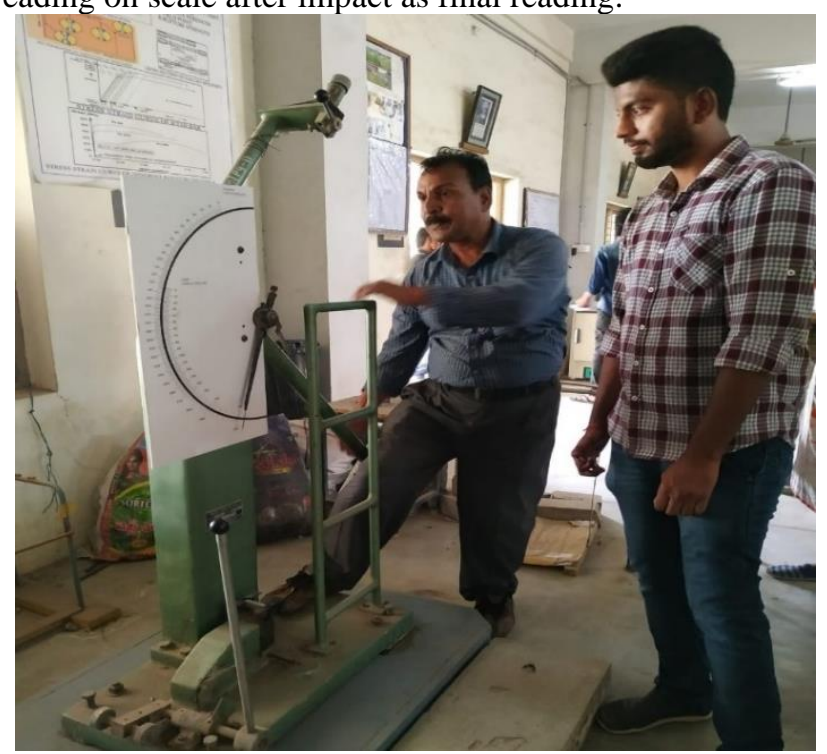

Figure 6: Charpy Impact test 


\section{Impact on Mechanical Properties of Hybrid Aluminum Metal Matrix Composites}

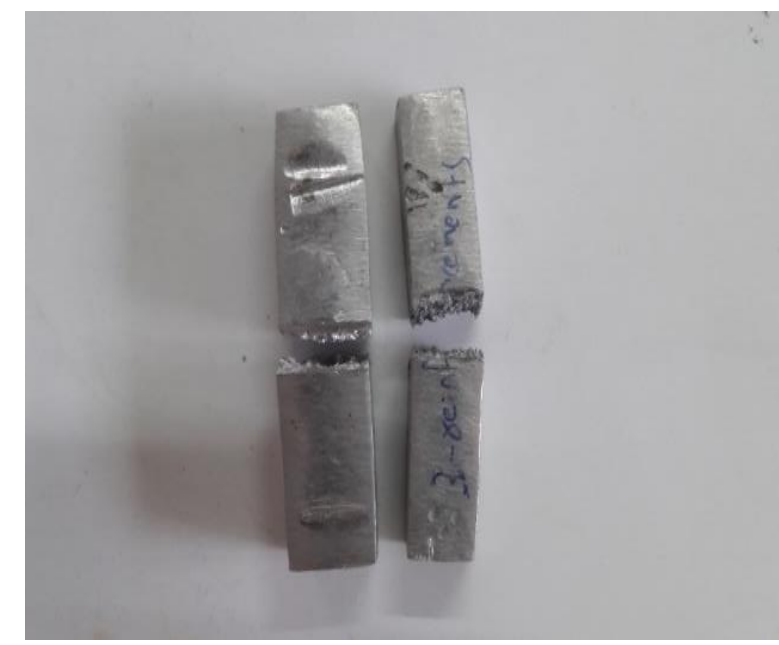

Figure 7: Samples after test

H. Brinell Hardness Test:

Brinell Hardness number is used to determine the hardness of material and the number can be find by a test called Brinell hardness test. In this test, we use a hardened steel ball indenter of diameter $5 \mathrm{~mm}$. The principle of this test is based on area of penetration of indenter in the specimen.

\section{Procedure:}

First of all, specimen is placed on the anvil and anvil is raised by rotating the hand wheel and specimen is brought in contact with ball indenter. After that load is applied by rotating crank/ lever at right side of the machine. Next the diameter of indent is produced on specimen and is measured using low powered microscope and brinell hardness number is calculated by the below formula.

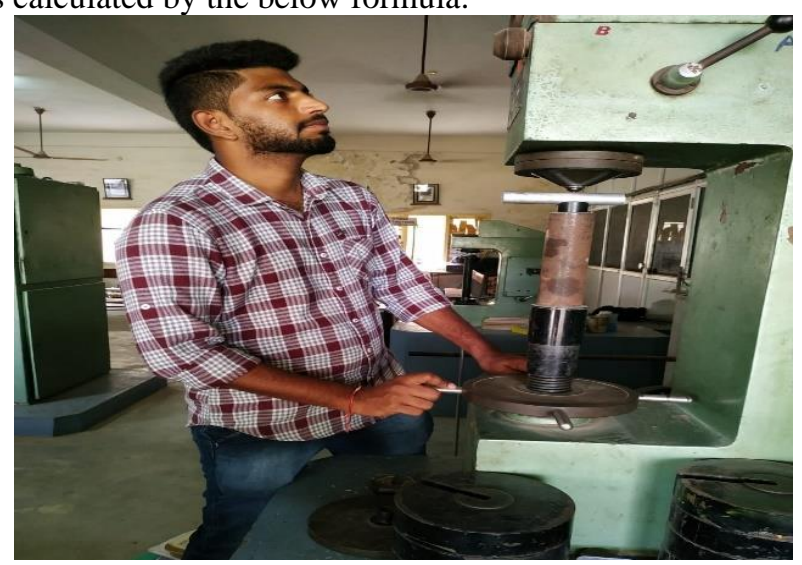

Figure 8: Brinell Hardness Test

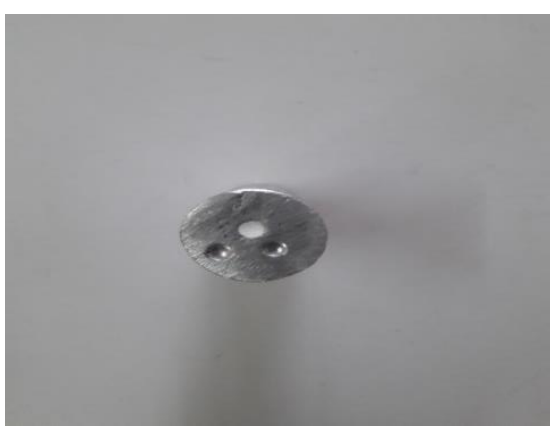

Figure 9: Sample after test

\section{Flexural Test:}

Flexural strength also known as modulus of rupture or bend strength is a material property defined as the stress in a material just before it yields in flexural test. The transverse bending test is most frequently employed in a specimen having circular or rectangular cross section, and is bent until fracture or yielding takes place using three-point flexural test. It represents highest stresses experienced with in the material at its moment of yield and is denoted with ' $\sigma$ '. For a circular cross section sample under a load in three point bending setup, flexural strength is given by $\sigma=\frac{F L}{\pi R 3}$

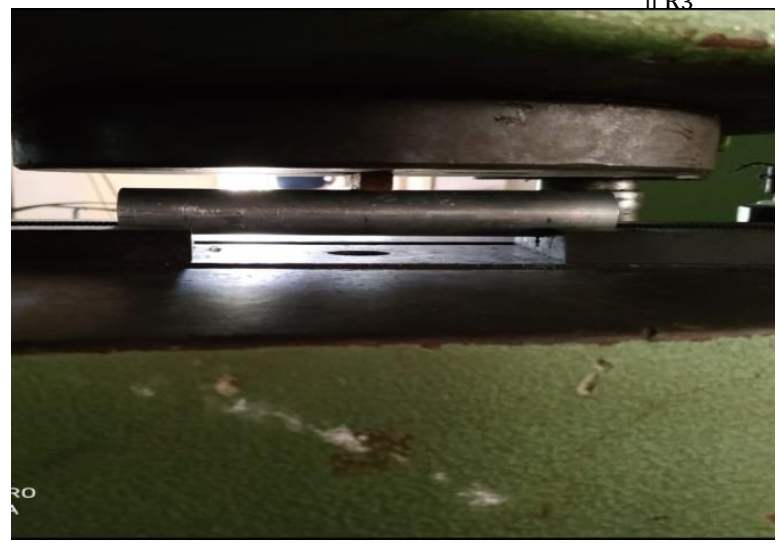

Figure 10: Flexural Test

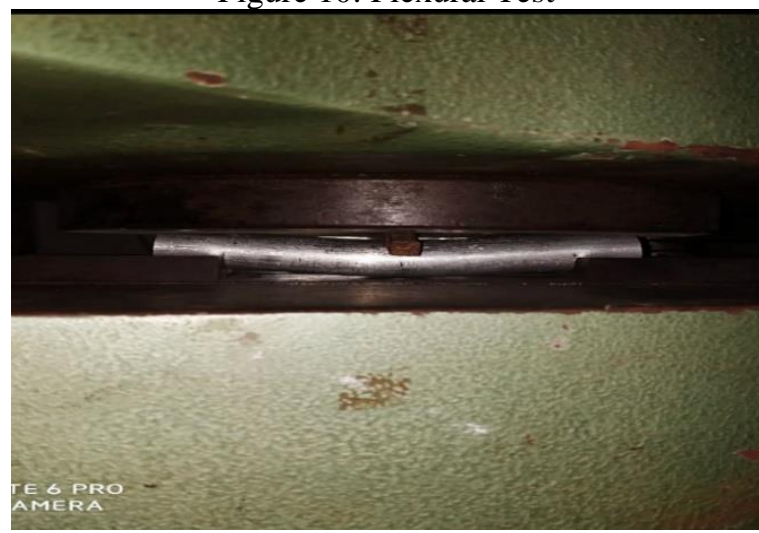

Figure 11: Sample after test

\section{RESULTS AND DISCUSSION}

J. Tensile Test:

Table 3: Tensile strength of composite samples vs Al 6061 T6 alloy

\begin{tabular}{|c|c|c|c|c|c|}
\hline Sample & $\begin{array}{c}\text { Max } \\
\text { Load } \\
(\mathrm{kN})\end{array}$ & $\begin{array}{c}\text { Load } \\
\text { at } \\
\text { break } \\
(\mathrm{kN})\end{array}$ & $\begin{array}{c}\text { Load } \\
\text { at 2\% } \\
\text { strain } \\
(\mathrm{kN})\end{array}$ & $\begin{array}{c}\text { UTS } \\
(\mathrm{MPa})\end{array}$ & $\begin{array}{c}\text { Youngs } \\
\text { Modulus } \\
(\mathrm{MPa})\end{array}$ \\
\hline 1 & 34.77 & 23.69 & 33.70 & 365.85 & 27981.43 \\
\hline 2 & 29.91 & 19.04 & 27.52 & 314.71 & 31150.97 \\
\hline 3 & 33.73 & 23.16 & 32.76 & 354.89 & 29451.32 \\
\hline 4 & 22.11 & 13.30 & 20.86 & 232.62 & 32681.84 \\
\hline
\end{tabular}




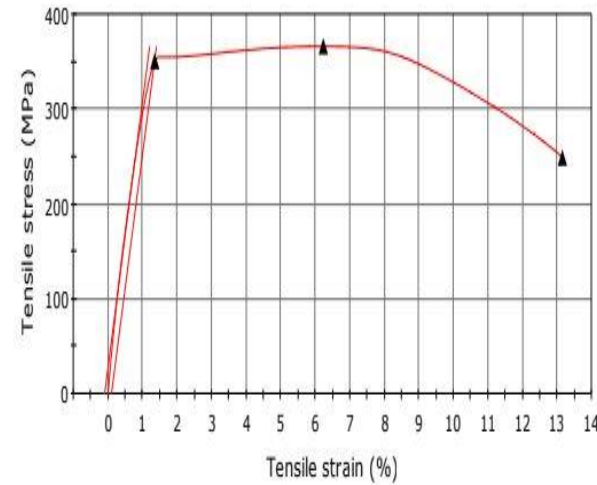

Figure 12: Stress-Strain curve of sample 1
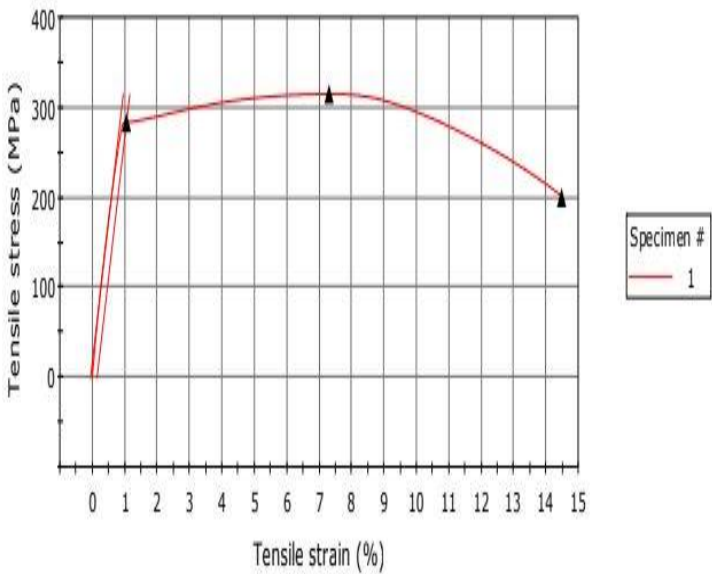

Figure 13: Stress-Strain curve of sample 2

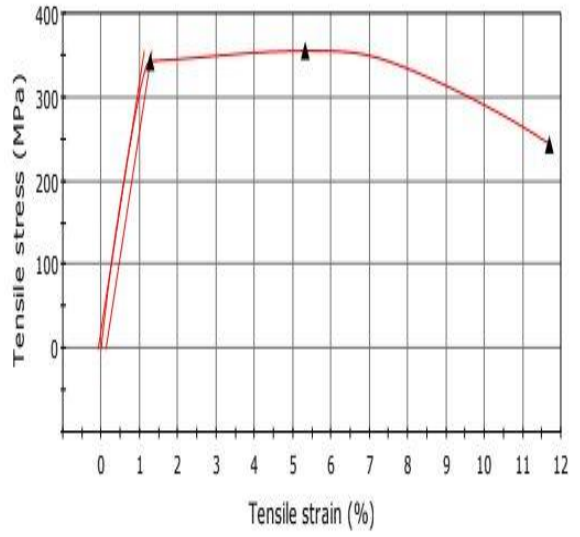

Figure 14: Stress- Strain Curve of Sample 3

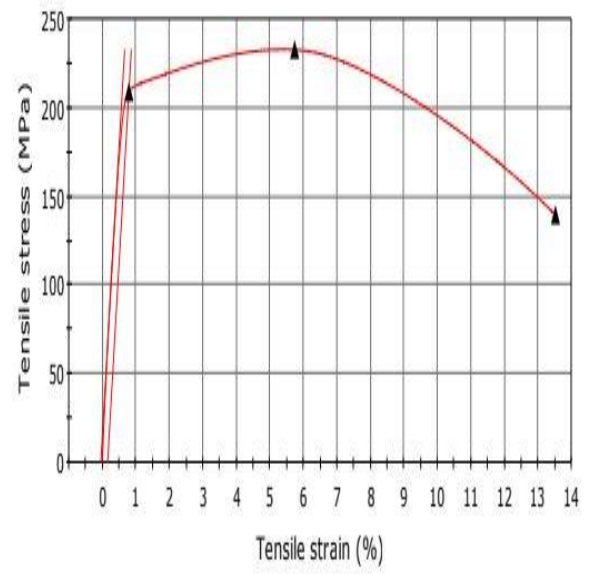

Figure 15: Stress- Strain curve of Sample 4
The above graphs represent the ultimate tensile strength and young's modulus is high for sample 1 rather than other three samples. It's because the three reinforcements aids to give high mechanical properties to Al alloy. Sample 3 has good ultimate tensile strength and young's modulus than sample 2 because of high strength and toughness values of Boron Carbide when compared with other reinforcements.

K. Charpy Impact Test:

Table 4: Charpy Impact test of composites vs Al 6061 T6

\begin{tabular}{|c|c|c|c|c|c|c|}
\hline $\begin{array}{c}\text { Sampl } \\
\mathbf{e}\end{array}$ & $\begin{array}{c}\mathbf{C} / \mathbf{S} \\
\text { area } \\
\mathbf{( m m}^{\mathbf{2}} \\
\mathbf{)}\end{array}$ & $\begin{array}{c}\text { Intial } \\
\mathbf{e n e r g} \\
\mathbf{y} \mathbf{Y}(\mathbf{J})\end{array}$ & $\begin{array}{c}\text { Error } \\
\text { in } \\
\text { readin } \\
\mathbf{g} \mathbf{g}(\mathbf{J})\end{array}$ & $\begin{array}{c}\text { Readin } \\
\mathbf{g} \text { after } \\
\text { Impact } \\
\mathbf{( J )}\end{array}$ & $\begin{array}{c}\text { Energy } \\
\text { absorbe } \\
\mathbf{d} \mathbf{( J )}\end{array}$ & $\begin{array}{c}\text { Toughnes } \\
\mathbf{s}\left(\mathbf{J} / \mathbf{m m}^{2}\right)\end{array}$ \\
\hline 1 & $10 \times 8$ & 300 & 6 & 28 & 266 & 3.325 \\
\hline 2 & $10 \times 8$ & 300 & 6 & 73 & 221 & 2.762 \\
\hline 3 & $10 \times 8$ & 300 & 6 & 82 & 212 & 2.625 \\
\hline 4 & $10 \times 8$ & 300 & 6 & 93 & 201 & 2.512 \\
\hline
\end{tabular}

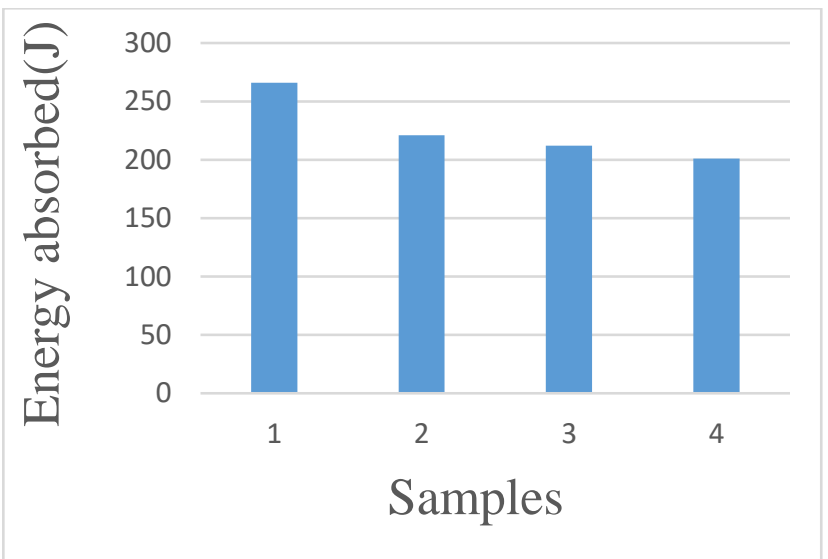

Figure 16: Energy absorbed by the samples

The above graph represents the Charpy Impact test results of samples. It clearly shows the chronological order of toughness of samples. Smaple 1 has high toughness and absorbs high energy followed by other three samples.

L. Brinell Hardness Test:

Table 5: Brinell Hardness test of composites vs Al 6061 T6

\begin{tabular}{|c|c|c|c|c|c|}
\hline $\begin{array}{c}\text { Sa } \\
\mathbf{m p l} \\
\mathbf{e}\end{array}$ & $\begin{array}{c}\text { Load } \\
\text { applie } \\
\mathbf{d}(\mathbf{k g f})\end{array}$ & $\begin{array}{c}\text { Diamete } \\
\text { r of } \\
\text { indenter } \\
\mathbf{( m m )}\end{array}$ & $\begin{array}{c}\text { Diameter of } \\
\text { three } \\
\text { indentations } \\
\mathbf{( m m )}\end{array}$ & $\begin{array}{c}\text { Average } \\
\text { diamete } \\
\text { r of } \\
\text { indentat } \\
\text { ion } \\
\mathbf{( m m}\end{array}$ & $\begin{array}{c}\text { Hardnes } \\
\mathbf{s} \text { from } \\
\text { B.H.N } \\
\text { formula }\end{array}$ \\
\hline 1 & 500 & 5 & 3.0 & 3.0 & 62.66 \\
& & & 3.0 & & \\
\hline 2 & 500 & 5 & 2.7 & 2.73 & 62.43 \\
& & & 2.7 & & \\
\hline 3 & 500 & 5 & 2.8 & 2.9 & \\
& & & 3.0 & & \\
\hline 4 & 500 & 5 & 2.7 & 2.6 & 62.36 \\
& & & 2.7 & & \\
\hline
\end{tabular}




\section{Impact on Mechanical Properties of Hybrid Aluminum Metal Matrix Composites}

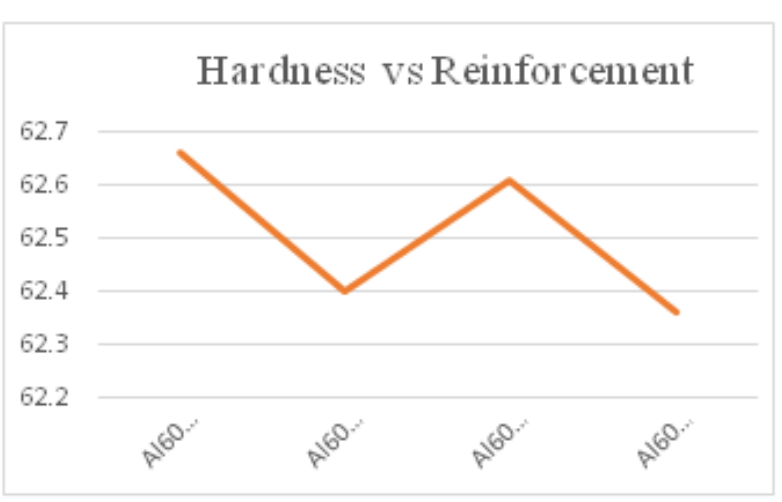

Figure 17: Hardness points of the samples

The hardness graph indicates that the three reinforced hybrid composite has high hardness value and sample 3 has second high hardness value when compared with sample 2 and sample 4. As hardness is high the hybrid composite sample has more energy to withstand heavy loads.

M. Flexural Strength:

Table 6: Flexural Strength of Composites vs Al 6061 T6 alloy

\begin{tabular}{|c|c|c|c|c|}
\hline Sample & $\begin{array}{c}\text { Bend } \\
\text { Starting } \\
\text { point } \\
\mathbf{( k N )}\end{array}$ & $\begin{array}{c}\text { Point } \\
\text { Break } \\
\text { Load } \\
\mathbf{( k N )}\end{array}$ & $\begin{array}{c}\text { Maximum } \\
\text { deflection } \\
\mathbf{( m m )}\end{array}$ & $\begin{array}{c}\text { Flexural } \\
\text { Strength } \\
\mathbf{( M P a )}\end{array}$ \\
\hline 1 & 2.75 & 41 & 0.049 & 201.883 \\
\hline 2 & 2.75 & 34 & 0.0893 & 167.415 \\
\hline 3 & 3 & 37.75 & 0.076 & 185.88 \\
\hline 4 & 2 & 23 & 0.1021 & 113.251 \\
\hline
\end{tabular}

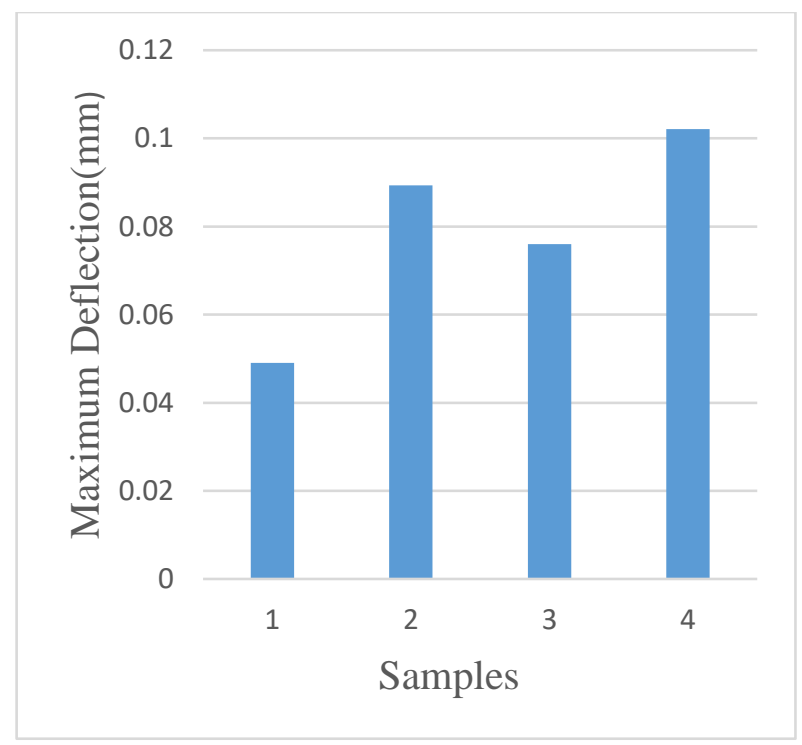

Figure 18: Maximum deflection of samples

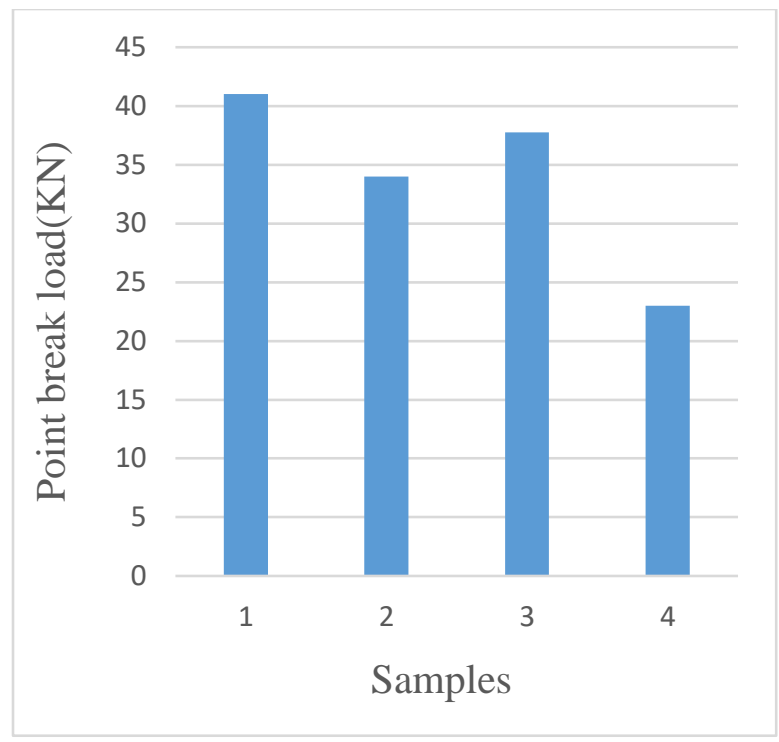

Figure 19: Point break load of samples

Flexural Strength gives two bar graphs which shows the maximum deflection and point break load. Sample 4 the Al alloy has maximum deflection when compared to other three samples because it has high ductile nature and less point break load capacity of its low flexural strength. Sample 2 has moderate flexural strength and exhibits moderate deflection.

N. Morphological Analysis using Scanning Electron Microscope (SEM):

SEM is a surface microscopy and uses behavior of electrons to create images. Its works on the principle of scattering of electron on the surface of sample and then the electrons bombard from the source and reflects from sample as primary electrons and secondary electrons. The electron beam from the source scans the sample in raster scan pattern and the reflected electrons are detected by electron detector and by analyzing the data 3D images are formed.

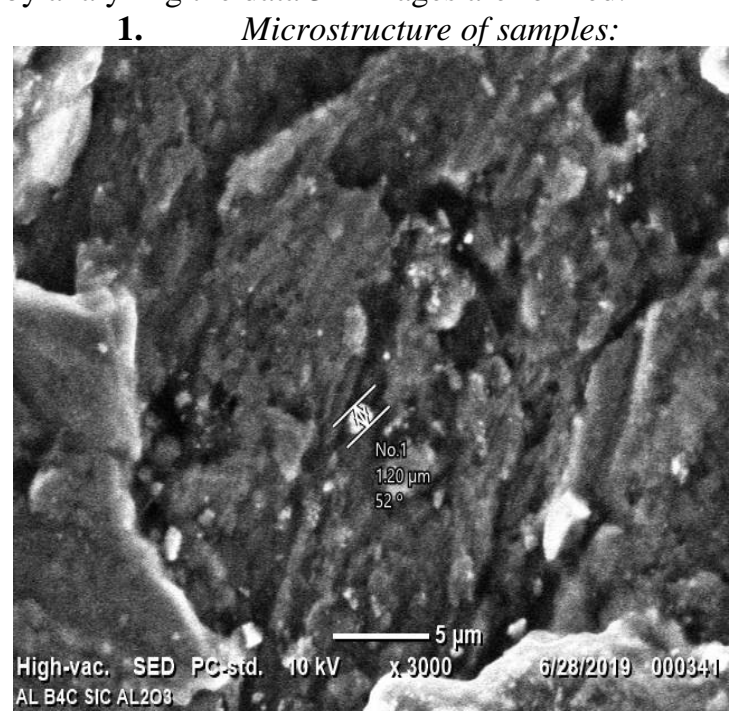

2. 


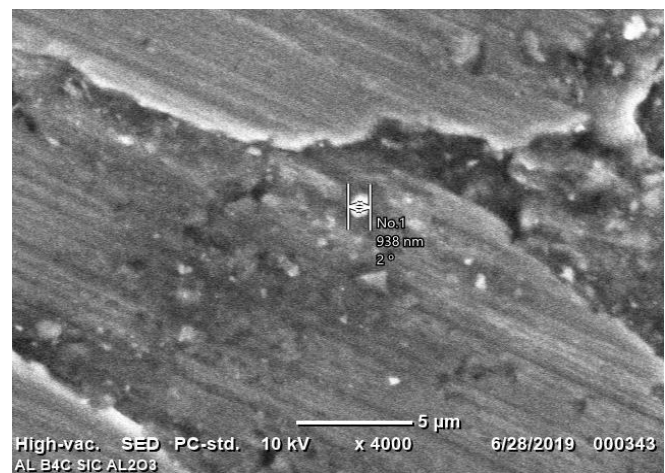

Figure 21: Sample 2 at $4000 \mathrm{X}$

The above figure shows the microstructure images of sample 1 which contains $\mathrm{Al} 2 \mathrm{O3}$, $\mathrm{SiC}, \mathrm{B} 4 \mathrm{C}$ as the reinforcements at $3000 \mathrm{X}$ and $4000 \mathrm{X}$ ranges. The microstructure image also revealed that there is good interfacial bonding between the reinforcements and $\mathrm{Al}$ matrix due to uniform distribution of reinforcements all over the matrix. Hence the mechanical properties of the sample are higher due to improvement in the crystallinity of sample. Also the black zone in the image signifies the micro cracks and porosity in the sample.

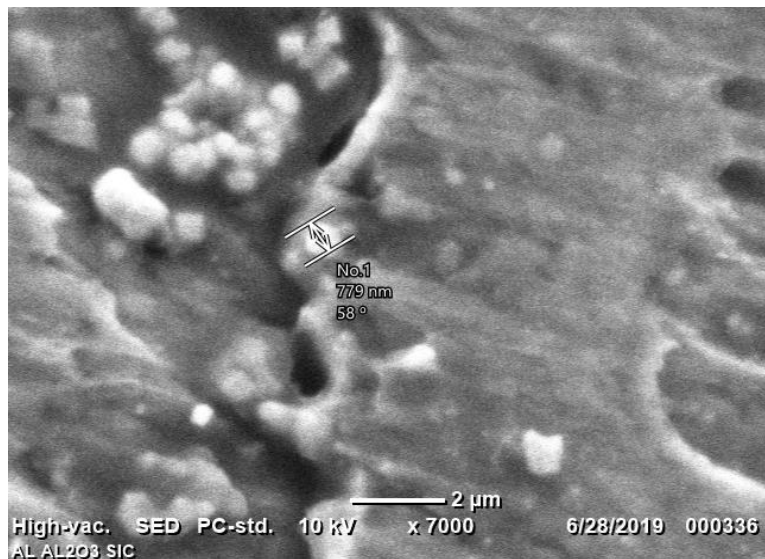

Figure 22: Sample 2 at $7000 \mathrm{X}$

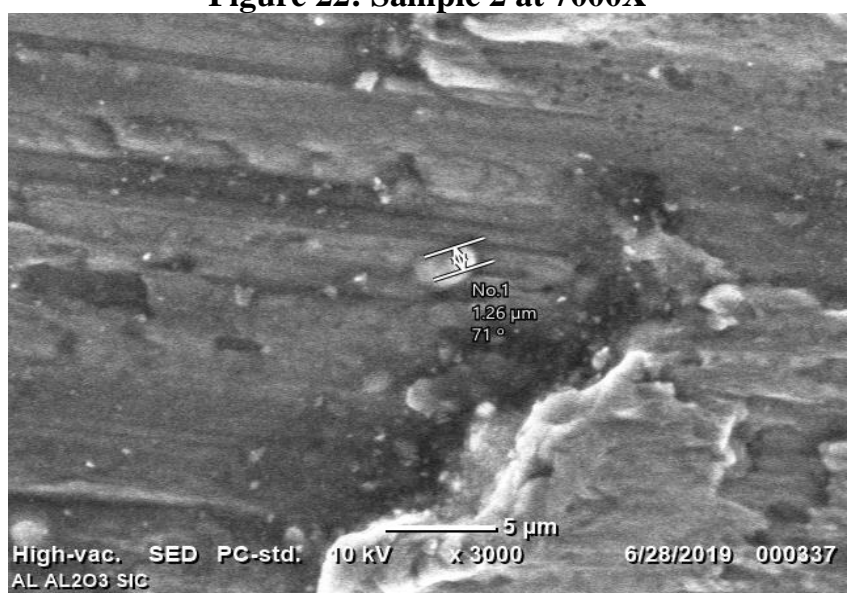

Figure 23: Sample 2 at $3000 \mathrm{X}$

The above figure shows the microstructure of sample 2 which consists $\mathrm{Al} 2 \mathrm{O} 3$ and $\mathrm{SiC}$ as reinforcements. In figure 1 the darker zone consists of SiC particles and lighter zone consists of $\mathrm{Al} 2 \mathrm{O} 3$ particles. Figure 1 shows accumulation of reinforcements due to improper stirring. Figure 2 shows the reinforcements of the matrix are predominantly located at center of image due to uniform distribution of reinforcements in that particular volume. However, only few de-bonding particles are observed when compared with sample 1.

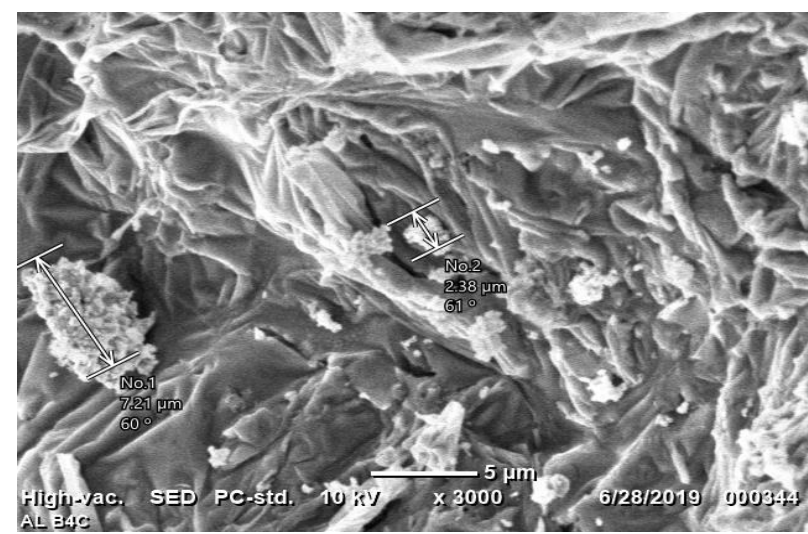

Figure 24: Sample 3 at $3000 \mathrm{X}$

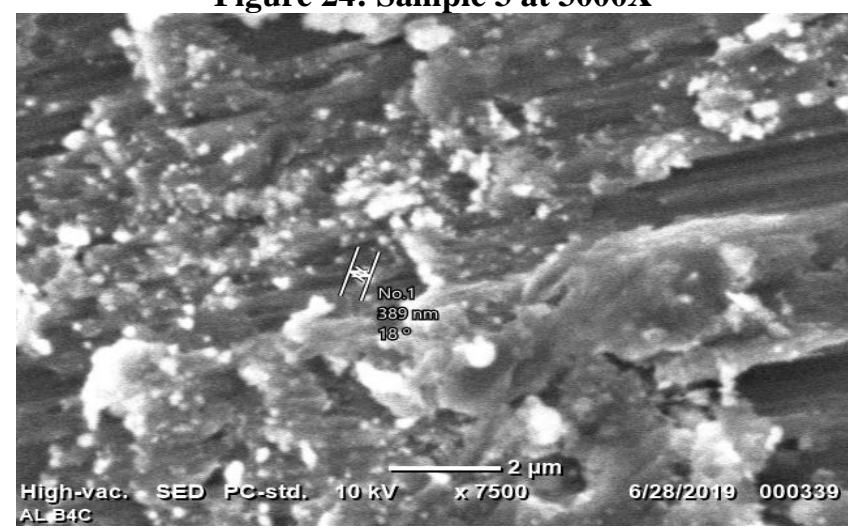

Figure 25: Sample 3 at $7500 \mathrm{X}$

These microstructure images exhibit the properties of sample 3 which consists B4C as reinforcement material. The above images are at $3000 \mathrm{X}$ and $7500 \mathrm{X}$ ranges. These figures 0show the accumulation of B4C reinforcement due to improper stirring but has good interfacial bonding between $\mathrm{Al}$ and $\mathrm{B} 4 \mathrm{C}$ particles due to uniform distribution of reinforcement all over the matrix. This helps to attain high mechanical properties when compared with sample 2. The black region in the images indicates micro cracks and porosity in the sample.

\section{CONCLUSIONS}

1. Hybrid Composites and composites were produced through stir casting technique in a three stage mixing process.

2. Tensile test specifies, Sample 1 has the high ultimate tensile strength and young's modulus and sample stands in the second place with good results showing they possess high strength.

3. Charpy Impact test gives the high toughness results for sample 1 and sample 2, this means the samples 1 and 2 absorbs greater amount of energy to get fractured.

4. Brinell Hardness test shows the hardness value for sample 1 and sample 3 is greater than the other 2 samples which means they have good resistance to plastic deformation.

5. Flexural rigidity test signifies sample 1 and sample 3 exhibits low deflection because of their high internal flexural resistance. Sample 2 and sample 4 shows high deflection because of their ductility nature.

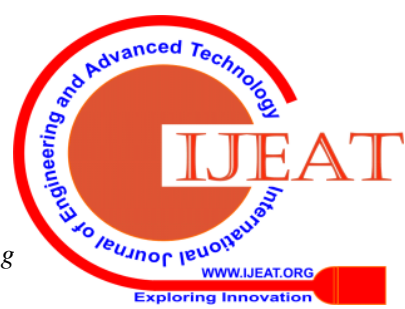




\section{Impact on Mechanical Properties of Hybrid Aluminum Metal Matrix Composites}

6. Through Scanning Electron Microscope, it was noted that reinforcements were non uniformly distributed in the matrix because of improper stirring. But they possess good interfacial bonding with the matrix which increases the mechanical properties of composites.

7. It was observed that sample 3 which consists boron carbide as reinforcement material has more mechanical properties than hybrid composite sample 2, because boron carbide possesses excellent properties, hence it can alone be replaced by $\mathrm{Al}_{2} \mathrm{O}_{3}$ and $\mathrm{B}_{4} \mathrm{C}$.

\section{REFERENCES}

1. McDanels, David L. "Analysis of stress-strain, fracture, and ductility behavior of aluminum matrix composites containing discontinuous silicon carbide reinforcement." Metallurgical transactions A 16, no. 6 (1985): 1105-1115.

2. Lloyd, D. J. "Particle reinforced aluminium and magnesium matrix composites." International materials review 39, no. 1 (1994): 1-23.

3. Dhanashekar, M., and VS Senthil Kumar. "Squeeze casting of aluminium metal matrix composites-an overview." Procedia Engineering 97 (2014): 412-420.

4. Han, Quanquan, Rossitza Setchi, and Sam L. Evans. "Synthesis and characterisation of advanced ball-milled Al-Al2O3 nanocomposites for selective laser melting." Powder Technology 297 (2016): 183-192.

5. Bodunrin, M. O., O. P. Oladijo, O. O. Daramola, K. K. Alaneme, and N. B. Maledi. "Porosity measurement and wear performance of Aluminium hybrid composites reinforced with silica sand and bamboo leaf ash." Annals of the Faculty of Engineering HunedoaraInternational Journal of Engineering 14, no. 1 (2016).

6. Moona, Girija, R. S. Walia, Vikas Rastogi, and Rina Sharma. "Aluminium metal matrix composites: A retrospective investigation." Indian Journal of Pure \& Applied Physics (IJPAP) 56, no. 2 (2018): 164-175.

7. Madhukar, P., N. Selvaraj, and C. S. P. Rao. "Manufacturing of aluminium nano hybrid composites: a state of review." In IOP Conference Series: Materials Science and Engineering, vol. 149, no. 1, p. 012114. IOP Publishing, 2016.

8. Gowrishankar T P, Manjunath L, Jegadeeswaran N "The Properties of an Aluminium Metal Matrix Composite - A review", International Journal of Advances in Scientific Research and Engineering (IJASRE), volume no.3, 2017.

9. B.Balamugundan, L.Karthikeyan, K.Karthik, C.Keerthi, "Enhancement of mechanical properties on aluminium alloys - A review", IOSR Journal of Mechanical and Civil Engineering (IOSRJMCE), pp.2320-3340, 2017.

10. Ralph, Brian, H. C. Yuen, and W. B. Lee. "The processing of metal matrix composites - an overview." Journal of materials processing technology 63, no. 1-3 (1997): 339-353.

11. Murayama, Harunobu, Ryong-Woon Shin, Jun Higuchi, Satoshi Shibuya, Tamaki Muramoto, and Tetsuyuki Kitamoto. "Interaction of aluminum with PHF $\tau$ in Alzheimer's disease neurofibrillary degeneration evidenced by desferrioxamine-assisted chelating autoclave method." The American journal of pathology 155, no. 3 (1999): 877-885.

12. G.S. Kataiah, Dr.D.P.Girish "The mechanical properties of aluminium 6061 - TiO2 composites" International Journal of Innovative Research and Development (Special Issue) volume no.5, 2016.

13. Christy, T. V., N. Murugan, and S. Kumar. "A comparative study on the microstructures and mechanical properties of Al 6061 alloy and the MMC Al 6061/TiB2/12p." Journal of Minerals and Materials Characterization and Engineering 9, no. 01 (2010): 57.

14. Dwivedi, Shashi Prakash, Shailesh Singh, and Harveer Singh Pali. "Macrostructure and Mechanical Properties of AA6082/SiC Composite Produced By Mechanical Stir Casting Process." In International Conference of Advance Research and Innovation, vol. 567. 2014

\section{AUTHORS PROFILE:}

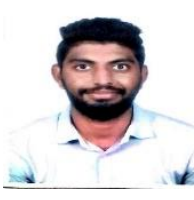

Sri Ram Murthy Paladugu- pursuing M.Tech in CAAD from Gayatri Vidya Parishad College of Engineering (Autonomous) and he has published four research papers in National and International journals. And his area of interest is in the field of composites materials.

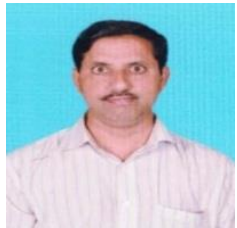

Dr. Y. Seetha Rama Rao- He is the Associate Professor in the Dept of Mechanical Engineering at Gayatri Vidya Parishad College of Engineering (Autonomous), Visakhapatnam, Andhra Pradesh, India. His area of research is Mechanical Vibrations, Composite materials and Machine Design. He published 30 research papers in Internal Journals and Conferences. He is a fellow member of the Institution of Engineers, a life member of ISTE, and member of Condition Monitoring Society

of India. 